\title{
ケーブルを介して曳航される滑空機系の固有值解析（第 1 報）*1 Eigenvalue Analysis of a Cable-Towed Glider System (Part I)
}

\author{
佐 藤 親 俊*2 $\cdot$ 柚 原 直 弘*3 \\ Chikatoshi SATOH and Naohiro Yuhara
}

Key Words : Stability and Control, Towed Glider, Cable Dynamics, Eigenvalue Analysis

\begin{abstract}
An analysis model for numerical estimation of eigenvalues of "a cable-towed glider" system is presented in this paper. This paper takes up longitudinal dynamics of the system. A cable dynamics is formulated as a distributed parameter system with flexibility extensibility and curvature of cable. For a specific example of a horizontal towing validity of the estimated eigenvalues is verified by the results of an identification of dominant modes found in the transient response of the system and stability of the system is analyzed based on root-loci regarding the relative height of a glider to a tug-plane. Modes dominantly affected by curvature of cable are also specified.
\end{abstract}

\section{1. は じめに}

テザー衛星や標的機の曳航, 飛行船や気球あるいはブイ の係留等のように，ケーブルを介して物体を曳航あるいは 係留するシステム (以下, 結合系と呼ぶ) の安定性は運用 条件に依存して大きく変化することが知られている．場合 によっては結合系が不安定となることもあるため, システ 么運用の安全上 , 結合系の安定性解析が重要である . 本論 は, 光のような結合系の例として滑空機の飛行機曳航系を 取り上げ, 固有値解析の立場から柔軟な弾性体ケーブルと 滑空機からなる系の縦面内の運動における安定性と固有振 動数特性を論じるものである .

結合系の安定性を固有値解析によって論じているこれま での研究を概観すると, 原典として Glauert ${ }^{11}$ の研究を挙 げることができるが，光こで用いられている結合系の運動 モデルは, ケーブルを質量の無い剛体棒で置き換え，乥の 棒の両端にピン結合された物体の運動を表したものとなっ ている. 兴の後の, 例えば O'hara ${ }^{2)}$ の研究では, Glauert ${ }^{11}$ のモデルにケーブルの弾性による伸縮の影響を反映させる よう，ケーブルを質量の無い 1 本の直線バネで置き換えてい る.しかし，これらの古典的研究ではケーブル自体の運動が 扱われていない. 弚の後, DeLaurier ${ }^{3)}$ の研究や Nakagawa ら ${ }^{4)}$ の研究に見られるように, 分布定数系として定式化さ れた柔軟なケーブルの運動を考慮した結合系の運動モデル が扱われている.しかし，これらにおいては，ケーブルを 非弾性体としているためにケーブルの軸方向の運動は省略 されている. 1990 年代の研究では, 弚の研究例は少ない ものの, さらにケーブルを柔軟な弾性ケーブルとして扱い，

\footnotetext{
*1 C) 2007 日本航空宇宙学会

平成 19 年 1 月 30 日原稿受理

$* 2$ 日本大学理工学部航空宇宙工学科

$* 3$ 日本大学総合科学研究所
}

ケーブルの半径方向と軸方向の運動が考慮されている . 中 でも，1993 年の de Matteis ${ }^{5)}$ による論文では, 結合系と して滑空機の飛行機曳航系を取り上げ, 曳航機に対する滑 空機の高度差 (相対高度) によっては系が不安定となるこ とを具体例において示している．また，1998 年にEtkin ${ }^{6)}$ は揚力を生じないとした標的機のような物体を曳航する結 合系の具体例で，相対高度によって不安定となる特性モ一 ドを抽出し，系の安定性を論じている．

これらに先立って，1973 年に著者ら ${ }^{7)}$ は，柔軟な弾性体 ケーブルの運動を双曲型偏微分方程式で, 曳航される滑空 機の運動を常微分方程式で記述して, 滑空機を曳航する飛 行機は定常飛行を続けるとした場合の結合系の時間応答を 求めている．光こでは, 飛行機曳航時に曳航機に対する滑 空機の相対高度を高い位置に保持する形態 (ハイトウ) と 低い位置に保持する形態 (ロウトウ) 乥れ光れにおいて, 滑 空機の昇降舵インパルス入力に対する滑空機の過渡応答に， 固有振動数が $1(\mathrm{rad} / \mathrm{sec})$ 以下の卓越的振動モードか現れ， ハイトウでの振動モードの方がより高い固有振動数を持ち， より明確な発散傾向を示すことを明らかにしている．关の 上で, 著者らは, 結合系の動特性が相対高度によってこの ように異なることが操縦性の違いの要因になっていると論 定している. 光の発端は, 従来, 滑空機パイロットによっ て指摘されていた位置保持操縦の難易, すなわち「ハイト ウでの操縦の方が , ロウトウでの光れよりも難しい」とさ れている事象の要因究明であった . さらに, 著者らは, こ のような結論の妥当性を固有值解析によって検証するため， 簡単化した結合系ダイナミックスに対して相対高度をパラ メータとする根軌跡を求め, 系の安定性や固有振動数の变 化を調べている8). しかし, 弚の結果からは, 上述の卓越 的振動モ一ドは見出されなかった . ケーブルの運動方程式 の線形化を行うと，半径方向の作用力項には，「結合系の 平衡状態におけるケーブルの曲率 (平衡曲率) と変動張力 
との積」が現れるが, 著者ら ${ }^{8)}$ は, 具体例では平衡曲率が 小さいため，この積を無視できるとした．本論では，この ことが一因であると考え，ケーブルの運動の定式化を見直 すと共に，結合系の固有值推定のための検討を加え，所期

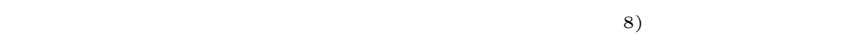
と固有値解析法が異なるため直接の比較はできないが, de Matteis ${ }^{5)}$ による定式化では，この積に関する作用力が考慮 されている.また, 弚こでは, ケーブルの質量を小さくし 相対高度が無いようにしてケーブルの平衡形状を直線的に してみると, 結合系の一つの特性モードの固有振動数が弾 性振動 (Von Flotow ら²) のいうバウンス) の值に近づく と述べられているが, 弚の理由が平衡曲率の影響によるも のであると言明されてはいない，本論では，結合系の推定 された特性モードを詳しく吟味し, 曳航時の滑空機の相対 高度が各特性モードに与える影響ならびにケーブルの平衡 曲率の影響を受ける特性モードも明らかにしている。

本論は以下のように構成されている.2 章では，まずケー ブルの運動方程式について述べる . 次に , この式に文献 8) で用いた離散化手法を適用して，結合系の固有值推定のた めの離散化モデルを導く . 3 章では, 離散化モデルによる 結合系の特性方程式 (振動数方程式) を示す. 4 章では, 文 献 8) の具体例を引用して固有值推定を行う. 兴の前段階で, 離散化数による特性モードの固有值の違いを検討し，推定 固有值と定めるに必要な離散化数を設定している. 产の上 で, 結合系における滑空機の時間応答に現れる卓越的振動 モードを同定して，推定固有値の妥当性を確かめている．ま た，平衡曲率の影響を強く受ける特性モードについて述べ る.これらを踏まえて, 相対高度をパラメータとする根軌 跡を求め, 結合系の相対高度に対する動特性の変化につい て論じる. 5 章は, 得られた結果のまとめである .

\section{2. 結合系の固有值推定のための離散化モデル}

本論で取り上げる「滑空機の飛行機曳航系」, すなわち， 曳航機・ケーブル・滑空機の結合系の縦面内の運動モデル は，1 本の捩りを受けない柔軟な弾性体ケーブルの運動方 程式とケーブルの両端での境界条件から構成される .

2.1 柔軟な弾性体ケーブルの運動方程式 第 1 図に示 すように， $Z_{\mathrm{E}}$ 軸を鉛直上方とする地面軸系 $\left(\mathrm{O}_{\mathrm{E}}-X_{\mathrm{E}}, Z_{\mathrm{E}}\right)$ に対して, 単位長さ当りの質量 $\mu$, 縦弾性係数 $E$, 断面積

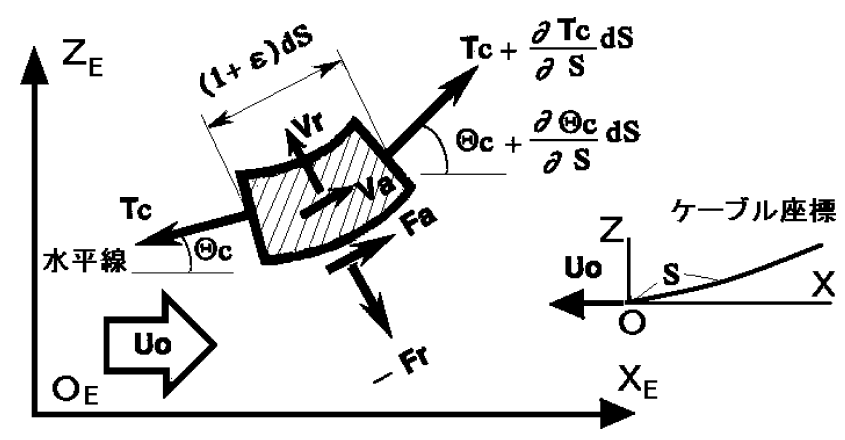

第1図 一樣気流中のケーブルの微小要素


ている場合のケーブルの運動を考える . 曳航機側の結合点 を原点 $\mathrm{O}$ とし，地面軸系に対して平行移動している動座標 系 $(\mathrm{O}-X Z)$ において, 原点 $\mathrm{O}$ を同じくするケーブル座標 $s$ と, 時間 $t$ を独立变数とする軸方向と半径方向の微小要 素の運動方程式は次の双曲型偏微分方程式 7 , 8) によって記 述される。

$$
\left.\begin{array}{l}
\frac{\partial T_{\mathrm{c}}}{\partial s}+\frac{\partial F_{\mathrm{a}}}{\partial s}=\mu\left(\frac{\partial V_{\mathrm{a}}}{\partial t}-V_{\mathrm{r}} \frac{\partial \Theta_{\mathrm{c}}}{\partial t}\right) \\
T_{\mathrm{c}} \frac{\partial \Theta_{\mathrm{c}}}{\partial s}+\frac{\partial F_{\mathrm{r}}}{\partial s}=\mu\left(\frac{\partial V_{\mathrm{r}}}{\partial t}+V_{\mathrm{a}} \frac{\partial \Theta_{\mathrm{c}}}{\partial t}\right) \\
\frac{\partial V_{\mathrm{a}}}{\partial s}-V_{\mathrm{r}} \frac{\partial \Theta_{\mathrm{c}}}{\partial s}=\left(\frac{1}{E A_{\mathrm{c}}}\right) \frac{\partial T_{\mathrm{c}}}{\partial t} \\
\frac{\partial V_{\mathrm{r}}}{\partial s}+V_{\mathrm{a}} \frac{\partial \Theta_{\mathrm{c}}}{\partial s}=\left(1+\frac{T_{\mathrm{c}}}{E A_{\mathrm{c}}}\right) \frac{\partial \Theta_{\mathrm{c}}}{\partial t}
\end{array}\right\}
$$

ここで, ケーブルの状態量 $T_{\mathrm{c}}, \Theta_{\mathrm{c}}, V_{\mathrm{a}}$ 乥して $V_{\mathrm{r}}$ 弚れ光れは 張力, 傾角 (水平に対するケーブルの微小要素の姿勢角), 絶対速度の軸方向成分と半径方向成分を表す. $F_{\mathrm{a}}$ と $F_{\mathrm{r}}$ は 空気力と重力からなる外力 $F$ の軸方向成分と半径方向成分 を示す. 式中，第 1 行は軸方向の運動方程式を，第 2 行は 半径方向の光れを表している. 弚して，第 3 行は軸方向の 連続の式から得られる歪速度を，第 4 行は半径方向の連続 の式から得られるケーブルの傾角の時間変化率を表す .

2.2 ケーブルの平衡状態 平衡状態では, ケーブルの 微小要素はケーブル座標の原点に対して相対速度を持たな

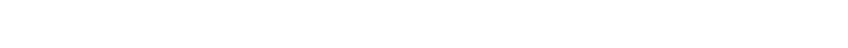
次式で書ける .

$$
\begin{aligned}
& V_{\mathrm{a} 0}(s)=-U_{0} \cos \left(\Theta_{\mathrm{c} 0}(s)\right) \\
& V_{\mathrm{r} 0}(s)=U_{0} \sin \left(\Theta_{\mathrm{c} 0}(s)\right)
\end{aligned}
$$

ケーブルの平衡方程式は , (1) 式から

$$
\left.\begin{array}{l}
\frac{\mathrm{d} T_{\mathrm{c} 0}(s)}{\mathrm{d} s}+\frac{\mathrm{d} F_{\mathrm{a} 0}(s)}{\mathrm{d} s}=0 \\
T_{\mathrm{c} 0}(s) \frac{\mathrm{d} \Theta_{\mathrm{c} 0}(s)}{\mathrm{d} s}+\frac{\mathrm{d} F_{\mathrm{r} 0}(s)}{\mathrm{d} s}=0
\end{array}\right\}
$$

と書ける .ここに ,ケーブルの状態量と外力に添字 0 をつけ て，弚れ光れの平衡状態での值を表している。以下， $T_{\mathrm{c} 0}(s)$ を平衡張力， $\Theta_{\mathrm{c} 0}(s)$ を平衡傾角と呼引゙ . $\Theta_{\mathrm{c} 0}(s)$ の $s$ に関 する变化率 $\mathrm{d} \Theta_{\mathrm{c} 0}(s) / \mathrm{d} s$ すなわち平衡曲率を $\kappa_{0}(s)$ と表し, 平衡状態での歪 (平衡歪) $T_{\mathrm{c} 0}(s) / E A_{\mathrm{c}}$ を $\varepsilon_{0}(s)$ と記す.

次に, 動座標系 $(\mathrm{O} \rightarrow X Z)$ の面内に位置する平衡状態 でのヶーブルの形状 (平衡形状) を以下のようにして求め る . まず，ケーブルに作用する空気力のケーブルの軸方向 の空力係数 $C_{F_{\mathrm{a}}}$, 半径方向の兰れを $C_{F_{\mathrm{r}}}$ とし, 弚れ光れは 文献 7,8) で用いているように $\Theta_{\mathrm{c}}(s, t)$, $\left[\left|\Theta_{\mathrm{c}}(s, t)\right| \leq \pi / 2\right]$ による次の関数で与えられるとする ${ }^{10)}$.

$$
\begin{aligned}
& C_{F_{\mathrm{a}}}\left(\Theta_{\mathrm{c}}(s, t)\right)=0.02 \cos \left(\Theta_{\mathrm{c}}(s, t)\right) \\
& C_{F_{\mathrm{r}}}\left(\Theta_{\mathrm{c}}(s, t)\right)=-\left[0.02+1.1\left|\sin \left(\Theta_{\mathrm{c}}(s, t)\right)\right|\right] \sin \left(\Theta_{\mathrm{c}}(s, t)\right)
\end{aligned}
$$




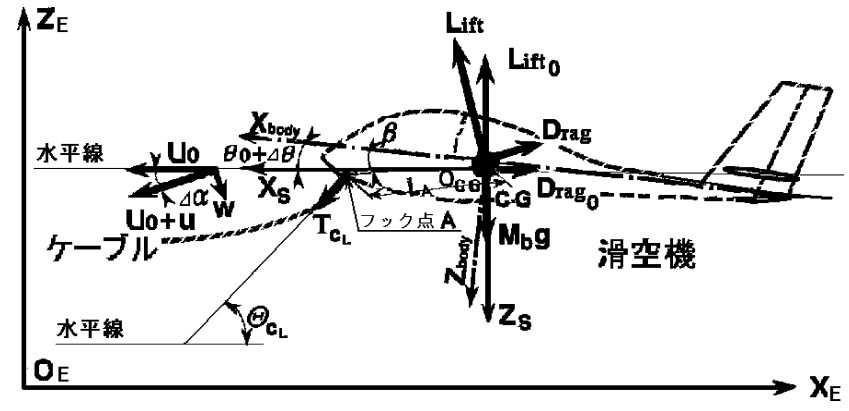

第 2 図 曳航された滑空機

そとて, 大気密度を $\rho$, ケーブル直径を $D_{\mathrm{c}}$, 重力加速度を $g$ で表すと, 無風下での平衡状態での外力の $s$ に関する変 化率，すなわち $(2)$ 式の $\mathrm{d} F_{\mathrm{a} 0}(s) / \mathrm{d} s$ と $\mathrm{d} F_{\mathrm{r} 0}(s) \mid \mathrm{d} s$ の关れ

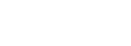

$$
\begin{aligned}
& \frac{\mathrm{d} F_{\mathrm{a} 0}(s)}{\mathrm{d} s}=\frac{1}{2} \rho U_{0}^{2} D_{\mathrm{c}} C_{F_{\mathrm{a}}}\left(\Theta_{\mathrm{c} 0}(s)\right)-\mu g \sin \left(\Theta_{\mathrm{c} 0}(s)\right) \\
& \frac{\mathrm{d} F_{\mathrm{r} 0}(s)}{\mathrm{d} s}=\frac{1}{2} \rho U_{0}^{2} D_{\mathrm{c}} C_{F_{\mathrm{r}}}\left(\Theta_{\mathrm{c} 0}(s)\right)-\mu g \cos \left(\Theta_{\mathrm{c} 0}(s)\right)
\end{aligned}
$$

\section{と書くことができる.}

従って, $T_{\mathrm{c} 0}(s)$ と $\Theta_{\mathrm{c} 0}(s)$ を求める問題は $(2)$ 式の初期值 問題となる. 初期値として $T_{\mathrm{c} 0}(L)$ と光の作用方向 $\Theta_{\mathrm{c} 0}(L)$ を与えることにする .この場合，第 2 图に示す，質量 $M_{\mathrm{b}}$ の滑空機に作用する, 重力 $M_{\mathrm{b}} g$, 水平定常飛行中の揚力 Lift $t_{0}$ と抗力 $\operatorname{Drag}_{0}$ ，並びに平衡張力 $T_{\mathrm{c} 0}(L)$ に関する力 の釣合い方程式

$$
\begin{aligned}
& M_{\mathrm{b}} g+T_{\mathrm{c} 0}(L) \sin \left(\Theta_{\mathrm{c} 0}(L)\right)-\text { Lift }_{0}=0 \\
& T_{\mathrm{c} 0}(L) \cos \left(\Theta_{\mathrm{c} 0}(L)\right)-\text { Drag }_{0}=0
\end{aligned}
$$

に対して，滑空機の釣合い迎角 $\alpha_{0}$ に対する Lift $_{0}$ と $\operatorname{Drag}_{0}$ が与えられると, $T_{\mathrm{c} 0}(L)$ と $\Theta_{\mathrm{c} 0}(L)$ は

$$
\begin{aligned}
& \Theta_{\mathrm{c} 0}(L)=\tan ^{-1}\left(\left(\text { Lift }_{0}-M_{\mathrm{b}} g\right) / \operatorname{Drag}_{0}\right) \\
& T_{\mathrm{c} 0}(L)=\operatorname{Drag}_{0} / \cos \left(\Theta_{\mathrm{c} 0}(L)\right)
\end{aligned}
$$

で求まる、弚こで, ケーブル座標 $s$ に対して逆向きに $(2)$ 式 の数值積分を行うと, 滑空機側フック点を原点とする, ケー ブル座標における平衡張力, 平衡歪乥れに平衡傾角, さら にケーブルの位置が定まることになる，兴の上で, 計算結 果を動座標系 $(\mathrm{O}-X Z)$ に置き換えると， $X$ (横位置) と $Z$ (相対緃位置)によって平衡形状が定まる．なお，相対高度 は平衡形状の, 曳航機側フック点に対する滑空機側フック 点の相対縦位置をいう.

2.3 ケーブルの運動方程式の線形化 ケーブルの状態量 を平衡状態量と微小擾乱量との和で表し, 平衡状態まわり に(1) 式を線形化する . 平衡状態量 $T_{\mathrm{c} 0}(s), \Theta_{\mathrm{c} 0}(s), V_{\mathrm{a} 0}(s)$

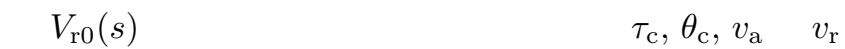
とすると, 状態量 $T_{\mathrm{c}}, \Theta_{\mathrm{c}}, V_{\mathrm{a}}$ と $V_{\mathrm{r}}$ は

$$
\begin{aligned}
& T_{\mathrm{c}}(s, t)=T_{\mathrm{c} 0}(s)+\tau_{\mathrm{c}}(s, t) \\
& \Theta_{\mathrm{c}}(s, t)=\Theta_{\mathrm{c} 0}(s)+\theta_{\mathrm{c}}(s, t) \\
& V_{\mathrm{a}}(s, t)=-U_{0} \cos \left(\Theta_{\mathrm{c} 0}(s)\right)+v_{\mathrm{a}}(s, t) \\
& V_{\mathrm{r}}(s, t)=U_{0} \sin \left(\Theta_{\mathrm{c} 0}(s)\right)+v_{\mathrm{r}}(s, t)
\end{aligned}
$$

で書けるので, (1) 式は微小擾乱量を状態変数とする, 次 の変係数の双曲型偏微分方程式で書き改められる .

$$
\left.\begin{array}{rl}
\frac{\partial \tau_{\mathrm{c}}}{\partial s} & =\mu \frac{\partial v_{\mathrm{a}}}{\partial t}+f_{\mathrm{a} \theta_{\mathrm{c}}}(s) \theta_{\mathrm{c}}+f_{\mathrm{a} v_{\mathrm{r}}}(s) v_{\mathrm{r}} \\
\frac{\partial \theta_{\mathrm{c}}}{\partial s} & =\frac{1}{T_{\mathrm{c} 0}(s)}\left\{\mu \frac{\partial v_{\mathrm{r}}}{\partial t}-\kappa_{0}(s) \tau_{\mathrm{c}}+f_{\mathrm{r} \theta_{\mathrm{c}}}(s) \theta_{\mathrm{c}}+f_{\mathrm{r} v_{\mathrm{r}}}(s) v_{\mathrm{r}}\right\} \\
\frac{\partial v_{\mathrm{a}}}{\partial s} & =\frac{1}{E A_{\mathrm{c}}} \frac{\partial \tau_{\mathrm{c}}}{\partial t}+\kappa_{0}(s) v_{\mathrm{r}} \\
\frac{\partial v_{\mathrm{r}}}{\partial s} & =\left(1+\varepsilon_{0}(s)\right) \frac{\partial \theta_{\mathrm{c}}}{\partial t}-\kappa_{0}(s) v_{\mathrm{a}}
\end{array}\right\}
$$

ここで, 第 2 行右辺の \{\} 内の第 2 項が文献 8) で省略して いる「平衡曲率と変動張力との積」である.なお, 外力の 微小擾乱量として, $\theta_{\mathrm{c}}$ と $v_{\mathrm{r}}$ による空気力の変動と, $\theta_{\mathrm{c}}$ に よる重力の変動を考慮しており, (3) 式の第 1 行と第 2 行 のこれらに関する微係数 $f_{\mathrm{a} \theta_{\mathrm{c}}}, f_{\mathrm{a} v_{\mathrm{r}}}, f_{\mathrm{r} \theta_{\mathrm{c}}}, f_{\mathrm{r} v_{\mathrm{r}}}$ 光れ光れは $\Theta_{\mathrm{c} 0}(s)$ で定まるので, 変係数になっている.

2.4 柔軟な弾性体ケーブルの運動方程式の離散化 曳 航機と曳航される滑空機の運動は, 通常, 定係数常微分方 程式によって表現される.対して，これら両機を結ぶ柔軟 な弾性体ケーブルの運動は (3) 式のような変係数の偏微分 方程式で表現される .このままであると, 結合系の固有值 解析が困難であることから, 固有值は変係数偏微分方程式 に何らかの離散化法を適用して数值解析的に推定されてい る.ちなみに de Matteis ${ }^{5}$ (は選点法を, Etkin ${ }^{6}$ (は有限差 分法を用いて，変係数偏微分方程式を定係数常微分方程式 として表し, 結合系全体を定係数常微分方程式系で表現し ている. 光れによって, 特性方程式の次数は限定され，推定 される固有值の数は有限となる. しかしながら，偏微分方 程式を含む結合系の固有值は理論的に無限個存在するので， 特性方程式の次数か限定されない離散化か望ましい．この 見地から, ケーブルを軸 (長手) 方向に分割し, 分割要素 ごとの变係数を定係数化するという離散化法 ${ }^{8,11)}$ を用いて， (3) 式の離散化を行う .

まず，時間 $t$ に関するラプラス変換の演算子を $\sigma$ として， (3) 式をラプラス変換する .ここで, ラプラス変換後の (3) 式を行列形式で表すと，次式で示せる .

$$
\frac{\mathrm{d} \boldsymbol{X}_{\mathrm{c}}(s, \sigma)}{\mathrm{d} s}=\boldsymbol{F}_{\mathrm{c}}(s, \sigma) \boldsymbol{X}_{\mathrm{c}}(s, \sigma)
$$

ここで, 状態ベクトル $\boldsymbol{X}_{\mathrm{c}}(s, \sigma)$ は

$$
\boldsymbol{X}_{\mathrm{c}}(s, \sigma)=\left[\hat{\tau}_{\mathrm{c}}(s), \hat{\theta}_{\mathrm{c}}(s), \hat{v}_{\mathrm{a}}(s), \hat{v}_{\mathrm{r}}(s)\right]^{\mathrm{T}}
$$

であり， $t$ に関するラプラス変換後の状態変数を表すため 変数光れ光れに記号^を付している. (4-a) 式の変係数の伝 
達行列 $\boldsymbol{F}_{\mathrm{c}}(s, \sigma)$ は

$$
\boldsymbol{F}_{\mathrm{c}}(s, \sigma)=\left[\begin{array}{cccc}
0 & f_{\mathrm{a} \theta_{\mathrm{c}}}(s) & \mu \sigma & f_{\mathrm{a} v_{\mathrm{r}}}(s) \\
\frac{-\kappa_{0}(s)}{T_{\mathrm{c} 0}(s)} & \frac{f_{\mathrm{r} \theta_{\mathrm{c}}}(s)}{T_{\mathrm{c} 0}(s)} & 0 & \frac{\mu \sigma+f_{\mathrm{r} v_{\mathrm{r}}}(s)}{T_{\mathrm{c} 0}(s)} \\
\frac{\sigma}{E A_{\mathrm{c}}} & 0 & 0 & \kappa_{0}(s) \\
0 & \left(1+\varepsilon_{0}(s)\right) \sigma-\kappa_{0}(s) & 0
\end{array}\right]
$$

である。

次いで , ケーブルを $N$ 個の要素に分割して , ケーブルの 曳航機側から要素ごとに順番付けし, 各要素における (4-c) 式の伝達行列の变係数を定係数で置き換える.ちなみに $s$ の变域 $\left(s_{i-1} \leq s \leq s_{i}, \Delta l_{i}=s_{i}-s_{i-1}\right)$ における $i$ 番目 のケーブルの分割要素について，(4-a) 式は，

$$
\frac{\mathrm{d} \boldsymbol{\xi}_{i}(s, \sigma)}{\mathrm{d} s}=\boldsymbol{F}_{\mathrm{c} i}(\sigma) \boldsymbol{\xi}_{i}(s, \sigma)
$$

と書ける .ここで, $\boldsymbol{\xi}_{i}(s, \sigma)$ は, $\boldsymbol{X}_{\mathrm{c}}(s, \sigma)$ に対応するケ一 ブルの分割要素 $i$ での状態ベクトル

$$
\boldsymbol{\xi}_{i}(s, \sigma)=\left[\tilde{\tau}_{\mathrm{c}}(s), \tilde{\theta}_{\mathrm{c}}(s), \tilde{v}_{\mathrm{a}}(s), \tilde{v}_{\mathrm{r}}(s)\right]_{i}^{\mathrm{T}}
$$

である.なお， $\boldsymbol{X}_{\mathrm{c}}(s, \sigma)$ の離散化後の状態変数を示すため， $\boldsymbol{\xi}_{i}(s, \sigma)$ の状態変数关れ光れに 記号を付している. また， $\boldsymbol{F}_{\mathrm{c} i}(\sigma)$ はケーブルの分割要素 $i て ゙ の$ 定係数伝達行列

$$
\boldsymbol{F}_{\mathrm{c} i}(\sigma)=\left[\begin{array}{cccc}
0 & f_{\mathrm{a} \theta_{\mathrm{c}} i} & \mu \sigma & f_{\mathrm{a} v_{\mathrm{r}} i} \\
\frac{-\kappa_{0 i}}{T_{\mathrm{c} 0 i}} & \frac{f_{\mathrm{r} \theta_{\mathrm{c}} i}}{T_{\mathrm{c} 0 i}} & 0 & \frac{\mu \sigma+f_{\mathrm{r} v_{\mathrm{r}} i}}{T_{\mathrm{c} 0 i}} \\
\frac{\sigma}{E A_{\mathrm{c}}} & 0 & 0 & \kappa_{0 i} \\
0 & \left(1+\varepsilon_{0 i}\right) \sigma & -\kappa_{0 i} & 0
\end{array}\right]
$$

を表す . 定係数伝達行列の要素の中で, 添字 $i$ を付した係

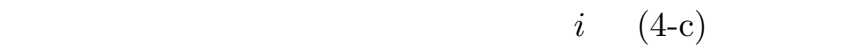
行列 $\boldsymbol{F}_{\mathrm{c}}(s, \sigma)$ の変係数の代表值として, $\Delta l_{i}$ 間における平 均値を与えることにする . ちなみに $\Delta l_{i}$ 間の平衡形状は平 衡曲率 $\kappa_{0 i}$ の円弧で表現される.

以上によって, ケーブルの運動方程式は, 变係数が分割 区間ごとに定係数化された偏微分方程式 ((5-a) 式) の $N$ 個の連結によって記述されることになる．なお，両端が固 定された場合のケーブル単体の運動モデルについては次節 の(4)に述べている .

2.5 ケーブルの境界条件 曳航機側と滑空機側のフック 点でピン結合されたケーブルの境界条件には文献 7,8) で与 えている条件，すなわち曳航機端では飛行速度が一定に維 持されるとして変動速度が無いという条件を与えると，变 動速度 $\tilde{v}_{\mathrm{a}}(0)$ と $\tilde{v}_{\mathrm{r}}(0)$ は零複素量 $\tilde{0}$ となり，ケーブルの分 割要素 1 で曳航機側の境界值 $\boldsymbol{\xi}_{1}(0, \sigma)$ は次式で書ける。

$$
\boldsymbol{\xi}_{1}(0, \sigma)=\left[\tilde{\tau}_{\mathrm{c}}(0), \tilde{\theta}_{\mathrm{c}}(0), \tilde{0}, \tilde{0}\right]^{\mathrm{T}}
$$

一方, ケーブルの分割要素 $N$ で滑空機側の境界条件を表 す境界值 $\boldsymbol{\xi}_{N}(L, \sigma)$ は次式で書ける .

$$
\boldsymbol{\xi}_{N}(L, \sigma)=\left[\tilde{\tau}_{\mathrm{c}}(L), \tilde{\theta}_{\mathrm{c}}(L), \tilde{v}_{\mathrm{a}}(L), \tilde{v}_{\mathrm{r}}(L)\right]^{\mathrm{T}}
$$

フック点 A (第 2 図) に作用する滑空機への入力 , すな わち $(7)$ 式の変動張力 $\tilde{\tau}_{\mathrm{c}}(L)$ と張力の作用方向の変化を表 す $\tilde{\theta}_{\mathrm{c}}(L)$ によって滑空機は非定常運動することになる. 光 の運動中の滑空機側のケーブルとの結合条件は, フック点 A における滑空機の変動速度と (7) 式のケーブルの変動速 度とがつねに合致しているという条件となる．この結合条 件は次のようにして求められる．質量 $M_{\mathrm{b}}$ ，ピッチ軸まわ りの慣性モーメント $I_{Y}$ の滑空機 (第 2 図) の運動を安定 軸系 $\left(\mathrm{O}_{\mathrm{CG}}-X_{\mathrm{S}}, Z_{\mathrm{S}}\right)$ による有次元運動方程式によって記述 する ${ }^{12)}$. 光の式を線形化し, 安定微係数 $Z_{\dot{w}}$ を無視できる とすれば，時間 $t$ に関するラプラス変換した滑空機の運動 方程式は次のようになる .

$$
\left.\begin{array}{l}
{\left[\sigma-X_{u}\right] \hat{u}-X_{w} \hat{w}-X_{\theta} \hat{\theta}} \\
\quad=X_{\tau} \tilde{\tau}_{\mathrm{c}}(L)+X_{\theta_{\mathrm{c}}} \tilde{\theta}_{\mathrm{c}}(L) \\
-Z_{u} \hat{u}+\left[\sigma-Z_{w}\right] \hat{w}-\left[\sigma\left(U_{0}+Z_{q}\right)+Z_{\theta}\right] \hat{\theta} \\
\quad=Z_{\tau} \tilde{\tau}_{\mathrm{c}}(L)+Z_{\theta_{c}} \tilde{\theta}_{\mathrm{c}}(L) \\
-M_{u}^{*} \hat{u}-M_{w}^{*} \hat{w}+\left[\sigma^{2}-M_{q}^{*} \sigma-M_{\theta}^{*}\right] \hat{\theta} \\
\quad=M_{\tau}^{*} \tilde{\tau}_{\mathrm{c}}(L)+M_{\theta_{\mathrm{c}}}^{*} \tilde{\theta}_{\mathrm{c}}(L)
\end{array}\right\}
$$

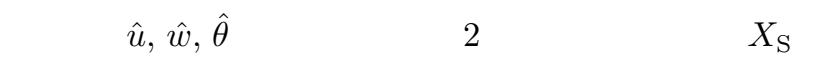
方向の变動速度, $Z_{\mathrm{S}}$ 軸方向の变動速度, 姿勢角変化を表 し, 滑空機のラプラス変換後の状態変数である. 本論では, 文献 13) を参考に有次元安定微係数を推算している.なお， (8) 式で , ケーブルから受ける $X_{\mathrm{S}}$ 方向と $Z_{\mathrm{S}}$ 方向の入力の 係数光れ以に示す。

$X_{\tau}=\cos \left(\Theta_{\mathrm{c} 0}(L)\right) / M_{\mathrm{b}}, \quad X_{\theta_{\mathrm{c}}}=-T_{\mathrm{c} 0}(L) \sin \left(\Theta_{\mathrm{c} 0}(L)\right) / M_{\mathrm{b}}$ $Z_{\tau}=\sin \left(\Theta_{\mathrm{c} 0}(L)\right) / M_{\mathrm{b}}, \quad Z_{\theta_{\mathrm{c}}}=T_{\mathrm{c} 0}(L) \cos \left(\Theta_{\mathrm{c} 0}(L)\right) / M_{\mathrm{b}}$ $M_{\tau}^{*}=M_{\tau}+M_{\dot{w}} Z_{\tau}, \quad M_{\theta_{\mathrm{c}}}^{*}=M_{\theta_{\mathrm{c}}}+M_{\dot{w}} Z_{\theta_{\mathrm{c}}}$ $M_{\tau}=-L_{\mathrm{A}} \sin \left(\beta^{*}\right) / I_{Y}, \quad M_{\theta_{\mathrm{c}}}=-T_{\mathrm{c} 0}(L) L_{\mathrm{A}} \cos \left(\beta^{*}\right) / I_{Y}$ また

$$
\begin{aligned}
& M_{u}^{*}=M_{u}+M_{\dot{w}} Z_{u}, \quad M_{w}^{*}=M_{w}+M_{\dot{w}} Z_{w}, \\
& M_{q}^{*}=M_{q}+M_{\dot{w}}\left(U_{0}+Z_{q}\right), \quad M_{\theta}^{*}=M_{\theta}+M_{\dot{w}} Z_{\theta}
\end{aligned}
$$

である.ここに， $\beta^{*}$ は角 $\left(\Theta_{\mathrm{c} 0}(L)-\left(\beta-\theta_{0}\right)\right)$ を表し， $\beta$ は $X_{\text {body }}$ 軸に対してフック点 $\mathrm{A}$ と滑空機の重心を結う線分 $L_{\mathrm{A}}$ のなす角 (第 2 図) であり， $\beta$ と $\theta_{0}$ との差角 $\left(\beta-\theta_{0}\right)$ は水平線に対して線分 $L_{\mathrm{A}}$ のなす角である.ちなみに， $\beta^{*}$ が零の場合には，平衡張力 $T_{\mathrm{c} 0}(L)$ の水平線に対してなす 傾角 $\Theta_{\mathrm{c} 0}(L)$ は差角 $\left(\beta-\theta_{0}\right)$ と一致し, $T_{\mathrm{c} 0}(L)$ は滑空機の 重心を通って作用する .

以上により，(8) 式を行列表現すると

$$
\boldsymbol{A}_{\mathrm{b}}(\sigma) \boldsymbol{X}_{\mathrm{b}}=\boldsymbol{\beta}\left[\tilde{\tau}_{\mathrm{c}}(L), \tilde{\theta}_{\mathrm{c}}(L)\right]^{\mathrm{T}}
$$


と書くことができ, 滑空機の状態ベクトル $\boldsymbol{X}_{\mathrm{b}}$ は,

$$
\boldsymbol{X}_{\mathrm{b}}=[\hat{u}, \hat{w}, \hat{\theta}]^{\mathrm{T}}
$$

システム行列 $\boldsymbol{A}_{\mathrm{b}}(\sigma)$ は，

$$
\boldsymbol{A}_{\mathrm{b}}(\sigma)=\left[\begin{array}{ccc}
{\left[\sigma-X_{u}\right]} & -X_{w} & -X_{\theta} \\
-Z_{u} & {\left[\sigma-Z_{w}\right]} & -\left[\sigma\left(U_{0}+Z_{q}\right)+Z_{\theta}\right] \\
-M_{u}^{*} & -\left[M_{w}^{*}\right] & {\left[\sigma^{2}-M_{q}^{*} \sigma-M_{\theta}^{*}\right]}
\end{array}\right]
$$

である.ケーブルからの入カベクトル $\left[\tilde{\tau}_{\mathrm{c}}(L), \tilde{\theta}_{\mathrm{c}}(L)\right]^{\mathrm{T}}$ に関 する入力行列 $\boldsymbol{B}$ は次式で書ける .

$$
\boldsymbol{B}=\left[\begin{array}{cc}
X_{\tau} & X_{\theta_{c}} \\
Z_{\tau} & Z_{\theta_{c}} \\
M_{\tau}^{*} & M_{\theta_{c}}^{*}
\end{array}\right]
$$

ここで, フック点 A でのケーブルの軸方向と半径方向の 変動速度 $\left[\tilde{v}_{\mathrm{aA}}, \tilde{v}_{\mathrm{rA}}\right]$ と (9-a) 式で支配される滑空機の状態 ベクトル $\boldsymbol{X}_{\mathrm{b}}$ との運動学的関係が結合行列 $\boldsymbol{C}(\sigma)$

$C(\sigma)=\left[\begin{array}{rrr}-\cos \Theta_{\mathrm{c} 0}(L) & -\sin \Theta_{\mathrm{c} 0}(L) & U_{0} \sin \theta_{0}+\sigma L_{\mathrm{A}} \sin \beta^{*} \\ \sin \Theta_{\mathrm{c} 0}(L) & -\cos \Theta_{\mathrm{c} 0}(L) & U_{0} \cos \theta_{0}+\sigma L_{\mathrm{A}} \cos \beta^{*}\end{array}\right]$ を用いて

$$
\left[\tilde{v}_{\mathrm{aA}}, \tilde{v}_{\mathrm{rA}}\right]^{\mathrm{T}}=\boldsymbol{C}(\sigma) \boldsymbol{X}_{\mathrm{b}}
$$

と書けるので , ケーブルと滑空機との結合条件は

$$
\left[\tilde{v}_{\mathrm{a}}(L), \tilde{v}_{\mathrm{r}}(L)\right]^{\mathrm{T}}=\left[\tilde{v}_{\mathrm{aA}}, \tilde{v}_{\mathrm{rA}}\right]^{\mathrm{T}}=\boldsymbol{C}(\sigma) \boldsymbol{X}_{\mathrm{b}}
$$

\section{として表される .}

以上により，時間 $t$ に関するラプラス変換後の結合系の 運動モデルは，

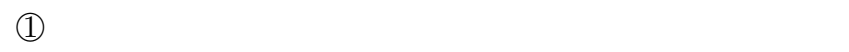
ル座標 $s$ に関する常微分方程式 ((5-a) 式) の $N$ 個の連立 によるケーブル全体の運動方程式，

(2) 兴の曳航機側の境界条件 ((6) 式),

(3) ケーブルによって拘束された滑空機側の境界条件 ((7) 式)，すなわち滑空機とケーブルとの結合条件 ((10) 式) に よって構成される . 本論では，この結合系の運動モデルを 離散化モデルと呼ぶ .

(4) 両端が固定された場合のケーブル単体の運動モデルは， (5-a) 式の $N$ 個の連結によって記述されたケーブルの運動 方程式, 曳航機側の境界条件 ((6) 式), 乥して滑空機側の 境界条件 ((7) 式) において結合点 A での変動速度が無い 条件 $\left(\left[\tilde{v}_{\mathrm{a}}(L), \tilde{v}_{\mathrm{r}}(L)\right]^{\mathrm{T}}=[\tilde{0}, \tilde{0}]^{\mathrm{T}}\right)$, すなわち

$$
\boldsymbol{\xi}_{N}(L, \sigma)=\left[\tilde{\tau}_{\mathrm{c}}(L), \tilde{\theta}_{\mathrm{c}}(L), \tilde{0}, \tilde{0}\right]^{\mathrm{T}}
$$

から構成される．任意な $\left[\tilde{\tau}_{\mathrm{c}}(0), \tilde{\theta}_{\mathrm{c}}(0)\right]^{\mathrm{T}}$ に対するケーブ ル単体の自由運動の同次方程式は次章に示す (14) 式で $\left[\tilde{v}_{\mathrm{a}}(L), \tilde{v}_{\mathrm{r}}(L)\right]^{\mathrm{T}}=[\tilde{0}, \tilde{0}]^{\mathrm{T}}$ と置くことによって得られる .こ の場合の固有值を定める特性方程式は光の同次方程式の行 列式 $\left|\Phi_{21}(\sigma)\right|$ を零とする式となる .

\section{3. 結合系の特性方程式}

離散化モデルの特性方程式（振動数方程式）を導くに際 し, ケーブル座標 $s$ に関するラプラス変換の演算子を $\lambda$ とする . まず , ケーブルの分割要素 $i$ の間のケーブルの 運動の一般解を求める . (5-a) 式の補助方程式は, 曳航用 ケーブルの材質では重根を持たないので, 補助方程式の根

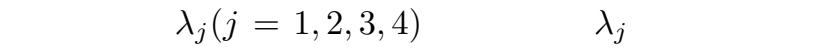
ル $\boldsymbol{p}_{j}$ を列べクトルに持つ変換行列 $\boldsymbol{P}_{i}\left(=\left[\boldsymbol{p}_{1}, \boldsymbol{p}_{2}, \boldsymbol{p}_{3}, \boldsymbol{p}_{4}\right]^{\mathrm{T}}\right)$ を用いて (5-a) 式は対角化され，一般解は 4 個の指数関数 $\exp \left(\lambda_{j} \Delta l_{i}\right)(j=1,2,3,4)$ によって与えられる .この場合 の遷移行列 $\boldsymbol{\Phi}_{i}(\sigma)$ は

$$
\boldsymbol{\Phi}_{i}(\sigma)=\boldsymbol{P}_{i} \operatorname{diag}\left[\exp \left(\lambda_{j} \Delta l_{i}\right)\right] \boldsymbol{P}_{i}^{-1}, \quad(i=1,2,3,4)
$$

と表され， $\boldsymbol{\Phi}_{i}(\sigma)$ を介して , ケーブルの分割要素 $i$ の両端 での状態ベクトル $\boldsymbol{\xi}_{i}\left(s_{i-1}, \sigma\right)$ と $\boldsymbol{\xi}_{i}\left(s_{i}, \sigma\right)$ とは,

$$
\boldsymbol{\xi}_{i}\left(s_{i}, \sigma\right)=\boldsymbol{\Phi}_{i}(\sigma) \boldsymbol{\xi}_{i}\left(s_{i-1}, \sigma\right)
$$

の関係て結ばれる .従って，ケーブル全体の遷移行列 $\boldsymbol{\Phi}_{i}(\sigma)$ はケーブルの分割要素の遷移行列の連結形で記述でき，滑 空機側の境界値 $\boldsymbol{\xi}_{N}(L, \sigma)$ と曳航機側の境界值 $\boldsymbol{\xi}_{1}(0, \sigma)$ とは

$$
\begin{aligned}
& \boldsymbol{\xi}_{N}(L, \sigma)=\boldsymbol{\Phi}(\sigma) \boldsymbol{\xi}_{1}(0, \sigma) \\
& \boldsymbol{\Phi}(\sigma)=\prod_{i=1}^{N} \boldsymbol{\Phi}_{N+1-i}(\sigma)
\end{aligned}
$$

なる関係で結ばれる.勿論，この関係は遷移行列の性質か らケーブル座標に関して可逆である。

次に，(12) 式に (6)，(7) 式の境界条件を与えて特解を求 める. (6) 式の $\tilde{v}_{\mathrm{a}}(0), \tilde{v}_{\mathrm{r}}(0)$ が零であるため, 行列演算上 , 遷移行列 $\boldsymbol{\Phi}(\sigma)$ を $2 \times 2$ の正方副行列から成る次のブロッ ク行列

$$
\boldsymbol{\Phi}(\sigma)=\left[\begin{array}{ll}
\boldsymbol{\Phi}_{11}(\sigma) & \boldsymbol{\Phi}_{12}(\sigma) \\
\boldsymbol{\Phi}_{21}(\sigma) & \boldsymbol{\Phi}_{22}(\sigma)
\end{array}\right]
$$

で表すと，(12) 式は次式で書ける .

$$
\begin{aligned}
& {\left[\tilde{\tau}_{\mathrm{c}}(L), \tilde{\theta}_{\mathrm{c}}(L)\right]^{\mathrm{T}}=\boldsymbol{\Phi}_{11}(\sigma)\left[\tilde{\tau}_{\mathrm{c}}(0), \tilde{\theta}_{\mathrm{c}}(0)\right]^{\mathrm{T}}} \\
& {\left[\tilde{v}_{\mathrm{a}}(L), \tilde{v}_{\mathrm{r}}(L)\right]^{\mathrm{T}}=\boldsymbol{\Phi}_{21}(\sigma)\left[\tilde{\tau}_{\mathrm{c}}(0), \tilde{\theta}_{\mathrm{c}}(0)\right]^{\mathrm{T}}}
\end{aligned}
$$

ここで, (9-a) 式の入力ベクトルを (13) 式で , (10) 式の 変動速度を $(14)$ 式で表すと，任意な $\left[\tilde{\tau}_{c}(0), \tilde{\theta}_{c}(0)\right]^{\mathrm{T}}$ に対す る (7) 式の滑空機側の境界条件が定まるので, 結合系の自 由運動に関する同次方程式は次式で書ける．

$\left[\boldsymbol{C}(\sigma) \boldsymbol{A}_{\mathrm{b}}^{-1}(\sigma) \boldsymbol{B} \boldsymbol{\Phi}_{11}(\sigma)-\boldsymbol{\Phi}_{21}(\sigma)\right]\left[\begin{array}{c}\tilde{\tau}_{\mathrm{c}}(0) \\ \tilde{\theta}_{\mathrm{c}}(0)\end{array}\right]=\left[\begin{array}{c}\tilde{0} \\ \tilde{0}\end{array}\right]$

従って，離散化モデルの特性方程式は (15) 式の行列式を零 とする式で記述される .なお, 特性方程式の文字式は長く なるため，弚の記述を省略する． 
第 1 表 滑空機の仕樣

\begin{tabular}{lrll}
\hline 質量 $: M_{\mathrm{b}}(\mathrm{kg})$ & 420 & 揚力傾斜 $(1 / \mathrm{rad})$ & 5.99 \\
慣性モーメント $: I_{\mathrm{b}}\left(\mathrm{kg} \mathrm{m}^{2}\right)$ & 703 & 尾翼谷積 $\left(\mathrm{m}^{3}\right)$ & 11.34 \\
主翼面積 $\left(\mathrm{m}^{2}\right)$ & 16 & 主翼取付角 $(\mathrm{rad})$ & 0.075 \\
緃横比 & 16 & $L_{\mathrm{A}}(\mathrm{m})$ & 2.5 \\
最大揚抗比 & 28 & $\beta(\mathrm{rad})$ & 0.07 \\
\hline
\end{tabular}

相対高度 $(-15 \mathrm{~m}<H<15 \mathrm{~m})$ に対する有次元安定微係数

\begin{tabular}{llllll}
$\left(X_{u}\right)$ & $-0.0253 \sim-0.0256$ & $\left(Z_{u}\right)$ & $-0.70 \sim-0.72$ & $\left(M_{u}^{*}\right)$ & $0.0238 \sim 0.0243$ \\
$\left(X_{w}\right)$ & $0.258 \sim 0.264$ & $\left(Z_{w}\right)$ & -3.89 & $\left(M_{w}^{*}\right)-0.286$ \\
$\left(X_{\theta}\right)-9.75 \sim-9.97$ & $\left(Z_{\theta}\right)$ & $0.351 \sim 0.356$ & $\left(M_{\theta}^{*}\right)$ & $-0.532 \sim-0.555$ \\
$\left(X_{q}\right)$ & 0.0 & $\left(U_{0}+Z_{q}\right)$ & 26.15 & $\left(M_{q}^{*}\right)-5.23$ \\
$\left(X_{\tau}\right) \quad 0.0231 \sim 0.0211$ & $\left(Z_{\tau}\right)$ & $-0.003 \sim 0.01$ & $\left(M_{T}^{*}\right) 0.0064 \sim-0.0138$ \\
$\left(X_{\Theta_{\mathrm{c}}}\right) 0.0469 \sim-0.1687$ & $\left(Z_{\Theta_{\mathrm{c}}}\right)$ & $0.351 \sim 0.356$ & $\left(M_{\Theta_{\mathrm{c}}}^{*}\right)-0.532 \sim-0.555$ \\
\hline
\end{tabular}

\section{4. 結合系の固有值推定}

4.1 具体例 ここで取り上げる結合系の具体例8) ( 面付近の高度を，時速 $100 \mathrm{~km}$ で水平定常飛行を続ける飛 行機が滑空機を曳航する系である. 滑空機と曳航用ヶーブ ルの仕樣を弚れ光れ第 1 表と第 2 表に示す。

また，飛行安全のため，ケーブル張力による過度な縦摇 れモーメントか飛行機と滑空機に作用しないように，通常， 相対高度 $H$ はケーブル長 $50 \mathrm{~m}$ に対して概ね-10〜10 $\mathrm{m} の$ 範囲内に採られている.想像されるように, 計算結果は, 相 対高度が高い場合の方が低い場合に比べて，ケーブルの平 衡状態における平衡曲率は大きく，平衡張力は高い值となっ ている．例として，相対高度が $-10 \mathrm{~m}$ と $10 \mathrm{~m}$ の場合の， 横位置 $X$ に対する, 相対縦位置による平衡形状, 平衡曲率 及び平衡張力を第 3 図に示す.なお，相対高度 $-10 \mathrm{~m}$ で骨 空機の釣合い姿勢角 $\theta_{0}$ すなわち釣合い迎角 $\alpha_{0}$ は 0.02208 $(\mathrm{rad}), 10 \mathrm{~m}$ では $0.02385(\mathrm{rad})$ で, 相対高度 $-10 \sim 10 \mathrm{~m}$ の範囲で $\theta_{0}$ の変化は概ね線形であった .

\section{2 結合系の固有值}

4.2.1 固有值の探索方法と範囲 結合系 (15) 式の特性


を同時に零とする複素パラメータ $\sigma$ すなわち固有值の実部 $\sigma_{\text {Re }}$ と虚部 $\sigma_{\operatorname{Im}}$ の探索を行う. 結合系は理論的に無限個の 固有值を持つが，実際に推定対象となる固有値は有限個で あるため探索範囲は限られることになる . 1 章で, 曳航され た滑空機自体の昇降舵のインパルス入力による過渡応答に 現れた卓越的振動モードの固有振動数が $1(\mathrm{rad} / \mathrm{sec})$ より も低いことを述べたが，曳航時の相対高度によっては，こ れよりも高くなる場合も想定されるので，本論では，固有 值の探索範囲を 0 10 ( rad/sec) の低周波数領域と定める

4.2 .2 ケーブルの分割要素数について 離散化モデルの 固有值は, ケーブルの分割要素数 $N$ (離散化数) を予め定 めた上で探索される. 従って, 探索固有值 (探索值) を推 定固有値とするには，探索値に影響を与えない離散化数を 設定する必要がある.上述の低周波数領域に存在した 6 個 の探索值に及ぼす離散化数の影響の一例を第 4 図に示す. 本図は，相対高度 $-10 \mathrm{~m}$ での結合系の， $N$ が 1 の場合の 探索值と $N$ を 50 まて増やした場合の探索値との比 $(\%)$ を示したものである．図中の特性モードには，探索值虚部

\begin{tabular}{|c|c|c|c|}
\hline 長さ: $L(\mathrm{~m})$ & 50 & 直径 : $D_{\mathrm{c}}(\mathrm{m})$ & 0.014 \\
\hline 線密度 : $\boldsymbol{\mu}(\mathrm{kg} / \mathrm{m})$ & 0.084 & ヤング率 : $E\left(\mathrm{~N} / \mathrm{m}^{2}\right)$ & $5.73 \times 10^{8}$ \\
\hline
\end{tabular}



第 3 図 曳航ケーブルの平衡形状 , 平衡曲率及び平衡張力

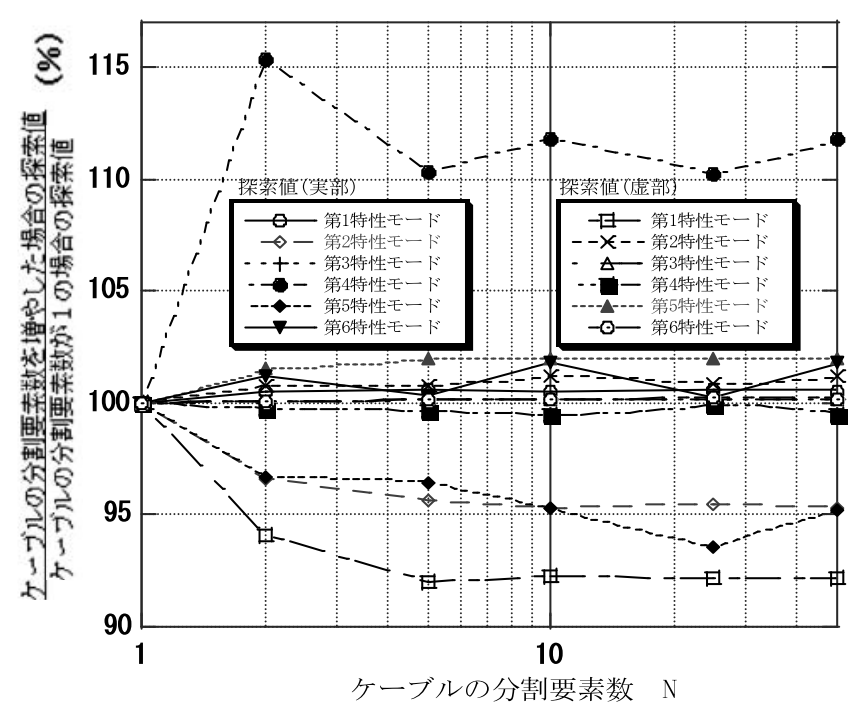

第 4 図 固有値の探索値に及ぼすケーブルの分割要素数の影響 (相対 高度 : $-10 \mathrm{~m}$ ) 
第 3 表 探索結果と固有振動数 $(\mathrm{rad} / \mathrm{sec})$

\begin{tabular}{|c|c|c|c|c|c|c|c|}
\hline \multirow{2}{*}{$\begin{array}{l}\text { 結合系の } \\
\text { 特性モード }\end{array}$} & \multicolumn{2}{|c|}{ 相対高度 : $-10(\mathrm{~m})$} & \multicolumn{2}{|c|}{ 相対高度 : 0 (m) } & \multicolumn{2}{|c|}{ 相対高度 : $10(\mathrm{~m})$} & \multirow{2}{*}{$\begin{array}{c}\text { (16) 式による } \\
\text { 固有振動数 }\end{array}$} \\
\hline & 実部 & 虚部 & 実部 & 虚部 & 実部 & 虚部 & \\
\hline 第 1 & 0.139 & 0.159 & 0.022 & 0.211 & -0.098 & 0.222 & $0.21 \sim 0.24$ \\
\hline 第 2 & -0.121 & 1.541 & -0.076 & 1.006 & 0.036 & 0.867 & $1.54 \sim 0.87$ \\
\hline 第 3 & -4.589 & 2.799 & -4.515 & 2.750 & -4.494 & 2.894 & $5.34 \sim 5.35$ \\
\hline 第 4 & -0.030 & 4.227 & -0.002 & 5.340 & -0.027 & 5.301 & $4.24 \sim 5.30$ \\
\hline 第 5 & -0.030 & 5.387 & -0.001 & 5.704 & -0.036 & 6.631 & $5.39 \sim 6.63$ \\
\hline 第 6 & -0.032 & 8.016 & -0.004 & 8.352 & -0.067 & 9.121 & $8.02 \sim 9.12$ \\
\hline
\end{tabular}

$\sigma_{\operatorname{Im}}$ の小さい順に，第 1 特性モード，第 2 特性モードのよ うに名を付けている. 図中， $N$ が10〜 50 では，モードの 比はいずれも一定となっている．すなわち，具体例の結合 系においては, 全長 $50 \mathrm{~m}$ のケーブルの分割要素長を $5 \mathrm{~m}$ から $1 \mathrm{~m}$ に設定すると，探索值には離散化数の影響か現れ ないものと判断できる . 同樣の結果が他の相対高度でも得 られている，乥こで，本論では，少ない誤差とすることか ら，結合系の推定固有值に $N$ が 50 の場合の探索値を用い ることにする . 以上のようにして求めた，相対高度 $-10,0$, $10 \mathrm{~m}$ における推定固有値を第 3 表に示す . 表中の固有振 動数は, $\sqrt{-1}$ を $j$ で表して, 各特性モードの探索値 $\left(\sigma_{\mathrm{Re}}\right.$, $\left.j \sigma_{\mathrm{Im}}\right)$ を, 減衰比 $\zeta$ と固有振動数 $\omega_{\mathrm{n}}$ の 2 次振動系の固有 值 $\left(-\zeta \omega_{\mathrm{n}}, j \omega_{\mathrm{n}} \sqrt{1-\zeta^{2}}\right)$ に対応させた，

$$
\omega_{\mathrm{n}}=\sqrt{\sigma_{\mathrm{Re}}^{2}+\sigma_{\mathrm{Im}^{2}}}
$$

から計算される值である .

4.2.3 結合系の特性モード ここでは,結合系の特性モ一 ドの特徵について述べる．弚れには，結合系の滑空機側フッ ク点に作用する平衡張力 $T_{\mathrm{c} 0}$ (牽引力) を推力とみなした 滑空機単体 $\left(T_{\mathrm{c} 0}\right.$ 付滑空機単体という) の運動, ケーブル 単体の運動兰れ光れが参考になる. 擾乱を受けた後の滑空 機には, 牽引力のみが关の作用方向を変えずにフック点に 作用していると仮定すると，(9-c) 式の有次元安定微係数に 相対高度で異なる $T_{\mathrm{c} 0}$ が考慮される．なお，この場合の滑 空機の運動は (9-a) 式においてケーブルからの入力を零と おくことによって表現される. $T_{\mathrm{c} 0}$ が140〜185 $(\mathrm{N})$ の範囲 で変る具体例では固有振動数の離れた二つの振動根が得ら れた . この $T_{\mathrm{c} 0}$ 付滑空機単体の, 縦短周期モ一ドの固有値 は $(-4.52(\mathrm{rad} / \mathrm{sec}), j 2.70(\mathrm{rad} / \mathrm{sec}))$ の近傍に，長周期 モードの固有值は $(-0.05(\mathrm{rad} / \mathrm{sec}), j 0.33(\mathrm{rad} / \mathrm{sec}))$ の 近傍に位置していた .ここで, 第 4 表に，相対高度 $-10 \mathrm{~m}$ の場合の，結合系の第 1 特性モードと第 3 特性モードにお ける滑空機の固有ベクトル各要素の, 姿勢角変化 $\theta$ に対す る大きさの比を示す. 同表には, $T_{\mathrm{c} 0}$ 付滑空機単体の長周 期モードと縦短周期モードの固有ベクトルの各要素の比を 併記している.第 3 表および第 4 表から，次のことが推察 される .

1) 結合系の第 1 特性モードの推定固有値は $T_{\mathrm{c} 0}$ 付滑空機 単体の長周期モードの固有值近傍に位置していることから， 本特性モードを長周期モードと称する．第 4 表を見ると， 本長周期モードはいわゆるフゴイドモードの特徵を示して いる. 本特性モードにおける $X_{\mathrm{S}}$ 軸方向の变動速度 $u$ は,
第 4 表 滑空機の固有ベクトル要素の大きさの比 (相対高度 : $-10 \mathrm{~m}$ )

\begin{tabular}{ccccc}
\hline 特性モード & 長周期 & 第 1 特性 & 縦短周期 & 第 3 特性 \\
\hline$|u / \theta|$ & 30.8 & 5.66 & 0.85 & 1.53 \\
$|w / \theta|$ & 2.7 & 2.02 & 1.0 & 49.1 \\
$|\theta / \theta|$ & 1 & 1 & 1 & 1 \\
$|\alpha / \theta|=\left|w / U_{0} \theta\right|$ & 0.10 & 0.077 & 0.038 & 1.84 \\
\hline
\end{tabular}

$T_{\mathrm{c} 0}$ 付滑空機単体の長周期モードにおける変動速度 $u$ と比 べて小さい .このことから，本特性モードでの滑空機の運 動はケーブルによって拘束されていることが伺える．従っ て, 本特性モードは $T_{\mathrm{c} 0}$ 付滑空機単体の長周期モードとは 異質と言える。

2) 結合系の第 3 特性モードの推定固有値は他の特性モ一 ドの弚れらと大きく離れ， $T_{\mathrm{c} 0}$ 付滑空機単体の緃短周期モ一 ドの固有值近傍に位置していることから，本特性モードを 短周期モードと称する.第 4 表から，本特性モードにおけ る姿勢角変化 $\theta$ と迎角変化 $\alpha$ は縦短周期モードにおける 弚れらとほぼ同じ大きさて変化することが伺える．従って， 本特性モードは, 主に滑空機の回転運動の動特性を表して いると考えて良い。

次に, 結合系の第 2 , 第 4 , 第 5 及び第 6 特性モードの特 徵を把握するため, ケーブルの平衡形状まわりに形成され る固有モード形状を計算した 。光れには, 境界値 ((13) 式) の中の $\tilde{\tau}_{\mathrm{c}}(L)$ に正の微小な変動張力 $\tilde{\tau}_{\mathrm{c}}^{*}(L)$ (実部: $9.8 \mathrm{~N}$, 虚部：0N) を設定した。例として，相対高度 $-10 \mathrm{~m}$ での ケーブル座標に対する固有モード形状を第 5-1 图と第 5-2 図に示す . 第 5-1 図はケーブルの平衡形状の位置からの軸 方向と半径方向の変位 $\tilde{e}_{\mathrm{a}}(s), \tilde{e}_{\mathrm{r}}(s)$ 弚れ光れを $X_{\mathrm{E}}$ 軸方向 に座標変換した変位 $\Delta X$ (実部) である.第 $5-2$ 図は $Z_{\mathrm{E}}$ 軸方向に座標変換した变位 $\Delta Z$ (実部) である．なお，変 位の虚部は実部と比べて微小であった . 第 4 , 第 5 及び第

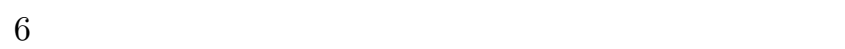
なわち弦の振動 1 次, 2 次及び 3 次モードの, 良く知られ た固有モード形状光れ光れに酷似している.このことから， これら特性モードは主としてケーブル自体の振動によって 支配されているものと推察される.ここで, 線密度 $\mu$, 長 さ $L$ のケーブルを伸びない系で置き換え，弚の両端を平衡 張力 $T_{\mathrm{c} 0}$ で直線とした弦の $n$ 次モードの固有振動数 $\omega_{t n}^{*}$ は $(n \pi / L) \sqrt{T_{\mathrm{c} 0} / \mu}$ となる . この式にケーブル仕樣 (第 2 表) と上述の相対高度で変る $T_{\mathrm{c} 0}$ を適用すると, 2 次モードの $\omega_{t 2}^{*}$ は $5.2 \sim 6.0(\mathrm{rad} / \mathrm{sec}), 3$ 次モードの $\omega_{t 3}^{*}$ は 7.9〜9.0 $(\mathrm{rad} / \mathrm{sec})$ となる.結合系の第 5 と第 6 特性モードの , (16) 




第 5-1図ケーブルの固有モード形状 $\Delta X$ (相対高度 : $-10 \mathrm{~m}$ )



第 5-2 図 ケーブルの固有モード形状 $\Delta Z$ (相対高度 : $-10 \mathrm{~m}$ )

式による固有振動数 (第 3 表) 弚れ光れは弦の $\omega_{t 2}^{*}$ と $\omega_{t 3}^{*}$ に近似しているが, 第 4 特性モードの光れは弦の 1 次モ一 ドの $\omega_{t 1}^{*}(2.6 〜 3.0(\mathrm{rad} / \mathrm{sec}))$ よりも高い値を示している 本論では, 弾性体ケーブルのこれらの振動を, 非弾性体の 弦の振動とは区別して，横振動と呼び，結合系の第 4 , 第

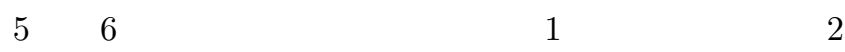
次モード，横振動 3 次モードと名付ける.残る結合系の第 2 特性モードは, 固有モード形状が第 4 特性モード (横振動 1 次モード) の光れと良く似ているものの，滑空機側結合 点に変位があることから, 第 2 特性モードは滑空機の運動 にも支配されていることが推察される．このことを裏付け るため, 結合系の第 2 特性モードと第 4 特性モード (横振 動 1 次モード) について, 上述の変動張力 $\tilde{\tau}_{\mathrm{c}}^{*}(L)$ に対する， 結合系における滑空機の固有べクトル及び滑空機側結合点 での変動速度 $\left(\tilde{v}_{\mathrm{a}}(L)\right.$ と $\left.\tilde{v}_{\mathrm{r}}(L)\right)$ と変位 $\left(\tilde{e}_{\mathrm{a}}(L)\right.$ と $\left.\tilde{e}_{\mathrm{r}}(L)\right)$ の大きさを求め，弚の結果を第 5 表に示す. 明らかに，滑 空機の運動の影響は，第 2 特性モードに認められるものの， 第 4 特性モード (横振動 1 次モード) では微小である . 従っ て , 結合系の第 2 特性モードは滑空機の運動とケーブルの 運動との干渉によって支配されているものと推断される .

4.2.4 推定された固有值の妥当性の検討 第 3 表に示し た具体例の推定固有值の妥当性を, 曳航された滑空機の昇 降舵インパルス入力に対する結合系の 60 秒間の過渡応答 から検討した . 兴のために, 本論では, 双曲型偏微分方程 式 ((3) 式) で表したケーブルの運動方程式を，特性曲線法 を用いて解いた . 例として，第 6 図及び第 7 図に相対高度 $10 \mathrm{~m}$ 及び $0 \mathrm{~m}$ での滑空機の $X_{\mathrm{S}}$ 軸 (前後) 方向の変動速度


モードを 2 次振動系の振動モードと見れば，乥の応答の対
第 5 表 結合系における滑空機の固有ベクトルと滑空機側結合点の変 動速度と変位 (相対高度 : $-10 \mathrm{~m}$ )

\begin{tabular}{llcc}
\hline \multicolumn{2}{c}{ 固有ベクトルの要素 } & $\begin{array}{c}\text { 結合系の第 } 2 \\
\text { 特性モード }\end{array}$ & $\begin{array}{c}\text { 結合系の第 } 4 \\
\text { 特性モード }\end{array}$ \\
\hline$|u| \times 10^{-2}$ & $(\mathrm{~m} / \mathrm{sec})$ & 1.9 & 0.59 \\
$|w| \times 10^{-2}$ & $(\mathrm{~m} / \mathrm{sec})$ & 0.79 & 0.27 \\
$|\theta| \times 10^{-2}$ & $(\mathrm{rad})$ & 0.1 & 0.018 \\
$\left|v_{\mathrm{a}}(L)\right| \times 10^{-2}$ & $(\mathrm{~m} / \mathrm{sec})$ & 1.3 & 0.14 \\
$\left|v_{\mathrm{r}}(L)\right| \times 10^{-2}$ & $(\mathrm{~m} / \mathrm{sec})$ & 1.7 & 0.088 \\
$\left|e_{\mathrm{a}}(L)\right| \times 10^{-2}$ & $(\mathrm{~m})$ & 0.81 & 0.0086 \\
$\left|e_{\mathrm{r}}(L)\right| \times 10^{-2}$ & $(\mathrm{~m})$ & 1.1 & 0.0050 \\
$\left|\tau_{\mathrm{c}}^{*}(L)\right|$ & $(\mathrm{N})$ & 9.8 & 9.8 \\
\hline
\end{tabular}

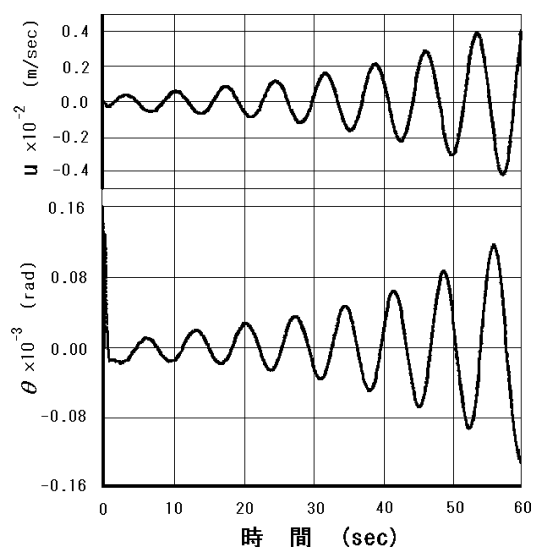

第 6 図 滑空機の $X_{\mathrm{S}}$ 軸方向の变動速度 $u(t)$ と姿勢角 $\theta(t)$ の過度応 答 (相対高度 : $10 \mathrm{~m}$ )

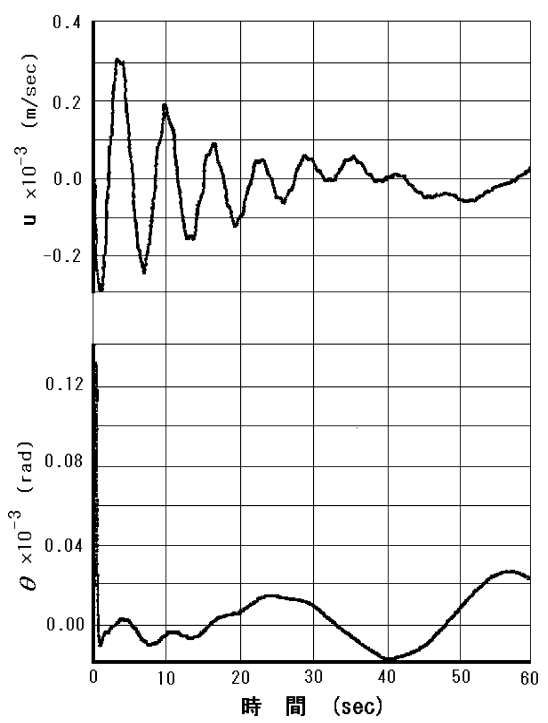

第 7 図 滑空機の $X_{\mathrm{S}}$ 軸方向の変動速度 $u(t)$ と姿勢角 $\theta(t)$ の過度応 答 (相対高度 : $0 \mathrm{~m}$ )

数減衰率は固有值の実部に, 減衰固有振動数は虚部に対応 する. 乥こで，これら特性值を求めてみると，以下のこと が推断される.

1) 第 6 図の $u(t)$ と $\theta(t)$ に現れている卓越的振動モ一 ドは対数減衰率 $0.043(\mathrm{rad} / \mathrm{sec})$ で発散しながら減衰固有 振動数 $0.89(\mathrm{rad} / \mathrm{sec})$ で振動しており，これは第 3 表に示 した結合系の第 2 特性モードの推定固有值 (実部 : 0.036 $(\mathrm{rad} / \mathrm{sec})$, 虚部 : $0.867(\mathrm{rad} / \mathrm{sec}))$ と一致している.この 
ことから, 相対高度 $10 \mathrm{~m}$ での滑空機の前後方向の変動速 度と姿勢角変化は第 2 特性モードによって支配されている と言える．

2) 第 7 図の $u(t)$ に現れている卓越的振動モ一ドは対数減 衰率 $-0.08(\mathrm{rad} / \mathrm{sec})$ で咸衰しながら減衰固有振動数 0.95 $(\mathrm{rad} / \mathrm{sec})$ で振動しており，これは第 3 表の結合系の第 2 特 性モードの推定固有值 (実部 : $-0.076(\mathrm{rad} / \mathrm{sec})$ ，虚部 : $1.00(\mathrm{rad} / \mathrm{sec}))$ に一致している。また， $\theta(t)$ の卓越的振 動モードは対数減衰率 $0.02(\mathrm{rad} / \mathrm{sec})$ で発散しながら減衰 固有振動数 $0.20(\mathrm{rad} / \mathrm{sec})$ て振動しており，これは結合系 の第 1 特性モード (長周期モード) の推定固有值（実部： $0.022(\mathrm{rad} / \mathrm{sec})$, 虚部 : $0.21(\mathrm{rad} / \mathrm{sec}))$ に一致している。 従って, 相対高度 $0 \mathrm{~m}$ における滑空機の前後方向の変動速 度は減衰する結合系の第 2 特性モードによって, 光の姿勢 角変化は結合系の第 1 特性モード (長周期モード) によっ て支配されていると言える。

以上により，本論の固有値推定の妥当性と結合系におけ る滑空機の過渡応答を支配する特性モードか確認された．

4.2.5 平衡曲率の影響を受ける特性モード 平衡曲率は 離散化モデルの定係数行列 ((5-c) 式) 内に現れる. 产れ故 に，平衡曲率の影響はすべての特性モードに及ぶことにな るが, ここでは，具体例の結合系において，光の影響を特 に強く受ける特性モードを明らかにした，弚れには，まず，


(零の平衡曲率) として表現した .このことによって (5-a) 式で表されるケーブルの運動は, 連続の式において軸方向 と半径方向に完全に分離され，ケーブルの半径方向の運動 には張力変動の影響が及ばないことになる .この場合の推 定固有値を (16) 式に当てはめてみると，(5-a) 式における 平衡曲率の有無の違いによる影響が, 特に結合系の第 2 特 性モードと第 4 特性モード（横振動 1 次モード）の固有振 動数に認められた . ちなみに , 第 3 図に示したケーブルの 平衡状態における平衡曲率をケーブルの分割要素光れぞれ において零とした場合 (ケーブルの折線近似) の第 2 特性 モードと第 4 特性モードの推定固有値と (16) 式による固有 振動数との比較を第 6 表に示す.

1) 第 6 表の第 4 (横振動 1 次) 特性モードの固有振動数 は, いずれも 4.2.3に述べた，弦の 1 次振動の $\omega_{t 1}^{*}$ に近い 值を示している. 対して, 第 3 表の平衡曲率が考慮されて

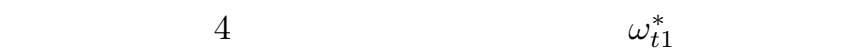
く, 相対高度 $-10 \mathrm{~m}$ で 1.6 倍， $10 \mathrm{~m}$ では 1.8 倍の值を示

第 6 表 ケーブルの各分割要素の平衡曲率を零とした場合の推定固有 值と (16) 式による固有振動数

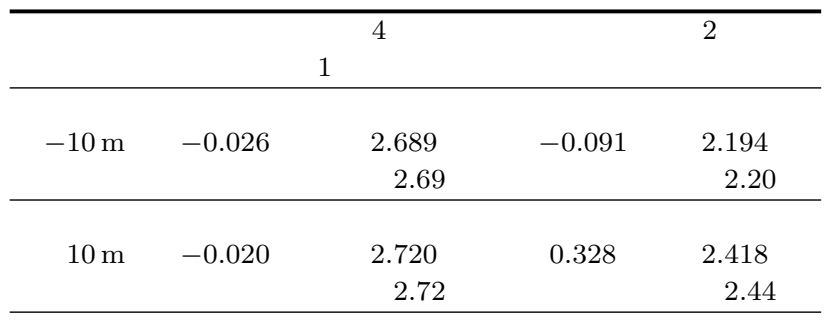

している． 4.1 で述べたように，相対高度が高くなると平 衡曲率は大きくなることから，第 4 特性モードの固有振動 数の増加は平衡曲率に依存していることがわかる.

2) ケーブルの伸縮や歪の変動を表すケーブルの軸方向の 運動を, ケーブルの分割要素数を 1 , かつ, 光の平衡曲率を 零 (直線ケーブル近似) として考える.この直線の弾性体 ケーブルを, 長さ $L$, 断面積 $A_{\mathrm{c}}$, 縦弹性係数 $E$ の 1 本の 直線バネで置き換え，一端を固定して他端に滑空機の質量 $M_{\mathrm{b}}$ に相当する質点を結合させる .このバネ一質点系の固有 振動数 $\omega_{\mathrm{sp}}^{*}$ は $\sqrt{E A_{\mathrm{c}} / M_{\mathrm{b}} L}$ によって与えられる.これに滑 空機の質量 $M_{\mathrm{b}}$ (第 1 表) とケーブル仕樣 (第 2 表) を適 用すると， $\omega_{\mathrm{sp}}^{*}$ は $2.05(\mathrm{rad} / \mathrm{sec})$ となる. 第 6 表に示した， ケーブルの分割要素光れぞれの平衡曲率を零とした場合の， 結合系の第 2 特性モードの固有振動数は, この $\omega_{\mathrm{sp}}^{*} に$ に近い ものとなっている.このことから，第 2 特性モードをバネ 振動モードと呼ぶことにする.第 3 表に示した結合系の第 2 特性モード (バネ振動モード) の固有振動数は, 平衡曲

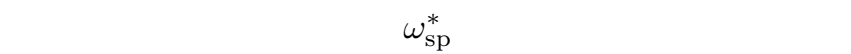
$-10 \mathrm{~m}$ で $\omega_{\mathrm{sp}}^{*}$ の $75 \%$ 值 , $10 \mathrm{~m}$ では $\omega_{\mathrm{sp}}^{*}$ の $42 \%$ 值となって いる。

以上のことから，相対高度が高くなるにつれて，すなわ ち平衡曲率の増加に伴って, 結合系の第 4 特性モ一ド (横 振動 1 次モード) の固有振動数は増加し, 第 2 特性モード (バネ振動モード) の关れは減少することか確認された .

4.2.6 相対高度に対する根軌跡 結合系の兰れ光れの特 性モードが曳航時の相対高度によって变化する樣子を詳細 に見るため, 相対高度をパラメータとする固有値の軌跡を 求めた . 第 8 図に相対高度 $-15 \sim 15 \mathrm{~m}$ の範囲の根軌跡 (実 軸目盛に対する虚軸目盛の比は $1: 10)$ を示す. 本図から , 以下のような結合系の安定性や固有振動数の変化を知るこ とができる .

1) 長周期モードは相対高度約 $2 \mathrm{~m}$ で安定限界を示し，こ れより低い相対高度で不安定である. 根虚部は 4.2 .3 に述



第 8 図 滑空機の飛行機曳航系の根軌跡 
ベた， $T_{\mathrm{c} 0}$ 付滑空機単体の長周期モードの $0.33(\mathrm{rad} / \mathrm{sec})$ よりも小さな約 $0.21(\mathrm{rad} / \mathrm{sec})$ を示し，相対高度に対して ほぼ一定となっている .

2) バネ振動モードは相対高度約 $7 \mathrm{~m}$ が安定限界であり， これよりも高い相対高度で不安定である . 虚部の值は相対 高度 $-15 \sim 7 \mathrm{~m}$ の安定領域で 2.2〜0.87 ( rad/sec) を示し 相対高度が高くなるにつれて低下する . 相対高度 $7 〜 15 \mathrm{~m}$ の不安定領域では虚部の值は約 $0.87(\mathrm{rad} / \mathrm{sec})$ と，ほぼ一 定となっている.

$3)$ 短周期モードの根は 4.2 .3 に述べた,$T_{\mathrm{c} 0}$ 付滑空機単体 の縦短周期モードの根 $(-4.52(\mathrm{rad} / \mathrm{sec}), j 2.70(\mathrm{rad} / \mathrm{sec}))$ 近傍に位置し，特に実部の変化を見ると，安定性は相対高 度が低くなるにつれて若干強くなっている．

4) 横振動 1 次, 2 次乥して 3 次モードはいずれも弱い安定 を示している.相対高度の増加と共に，虚部の值は大きくな り, 横振動 1 次モードの固有振動数は 2.7〜 $5.5(\mathrm{rad} / \mathrm{sec})$, 横振動 2 次モードの光れは 5.3〜 7.4 ( rad/sec), 横振動 3 次モードの炎れは 7.8〜10.1 ( $\mathrm{rad} / \mathrm{sec})$ を示している.

5) 相対高度 $2 \sim 7 \mathrm{~m}$ の範囲で, 以上に述べた 6 個の特性 モードすべてが安定である .

ところで，1章で述べたように，著者らは，滑空機のパイ ロットによって指摘されている位置保持操縦の難易の要因 は, 結合系における滑空機の過渡応答の卓越的振動モード の特性が相対高度によって異なることにあるとした7). 本 論 4.2 .4 で, 光の特性の違いをより詳細に述べ, 本節で上 記結論を裏付けている．すなわち同定された結合系の第 2 特性モード (バネ振動モード) と第 1 特性モード (長周期 モード) の根軌跡 (第 8 図) からわかるように，滑空機の パイロットには, 相対高度 $7 \mathrm{~m}$ 以上のハイトウでバネ振動 モードの, $2 \mathrm{~m}$ 以下のロウトウでは長周期モードの安定化 のための操縦が要求されることになる . 特に, 長周期モー ドの固有振動数に比べ約 4 〜 倍高い固有振動数を持つバネ 振動モードの安定化の方がパイロットのワークロードが大 きく，このことが飛行機曳航時の滑空機のハイトウでの位 置保持操縦が難しいとされている原因であると推断される.

\section{5.む す び}

本論では,「曳航機・ケーブル・滑空機」の結合系の固有 值を推定するための離散化モデルを示した .これを滑空機 の飛行機曳航の具体例に適用して，低周波数領域における 固有值を推定し, 曳航形態による位置保持操縦の難易をも たらす要因について論じた．以下に，关の結果をまとめる．

1) 結合系の特性モードの特徵を明らかにし，㫕れらは， ケーブルの運動と滑空機の運動との干渉に支配されるバネ 振動モード, 主として滑空機単体の運動に支配される長周 期モードと短周期モード, 光して主にケーブルの運動に支 配される横振動 1 次 , 2 次, 3 次モードであると判別された .

2) 本論で行った固有值推定によって, 曳航された滑空機
の昇降舵インパルス入力による過渡応答に卓越的に現れる 振動モードは第 1 特性モード (長周期モード) と第 2 特性 モード (バネ振動モード) であることが明確に同定された .

3) 特定された特性モードの中でも，とりわけ，横振動 1 次モードとバネ振動モードの固有振動数に平衡曲率の影響 か認められた . 相対高度が高くなるにつれて , すなわち平 衡曲率が大きくなるにつれて, 横振動 1 次モードの固有振 動数は増加し, バネ振動モードの光れは減少する .

4) 結合系の推定固有值の相対高度による変化を根軌跡と して求めた．これにより，特性モードすべてが安定である 曳航時の相対高度の範囲が存在すること, 钅の範囲よりも 高い相対高度ではバネ振動モードが不安定で，低い相対高 度では長周期モードが不安定であることが判明した .さら に，長周期モードの固有振動数と比べてバネ振動モードの 光れは約 4〜8 倍高く，このことがロウトウに比べてハイト ウでの位置保持操縦を難しくしていると推断した .

終りに, 上記 3$)$ の, 結合系のバネ振動モードと横振動 1 次モードの固有振動数に平衡曲率が影響する理由, ならび に4)の，バネ振動モードと長周期モードが相対高度によっ て不安定化するメカニズムについては第 2 報て論じる .

\section{参 考 文 献}

1) Glauert, H.: The Stability of a Body Towed by a Light Wire, R\&M 1312, Aeronautical Research Council, Great Britain, London, 1930.

2) O'hara, F.: Extension of Glider Tow Cable Theory to Elastic Cables Subject to Air Forces of a Generalized Form, R\&M 2334, Aeronautical Research Council, Great Britain, London, 1945.

3) DeLaurier, J. D.: A Stability Analysis of a Cable-Body System Totally Immersed in a Fluid Stream, NASA CR 2021, 1972 .

4) Nakagawa, N. and Obata, A.: Longitudinal Stability Analysis of Aerial-Towed Systems, J. Aircraft, 29 (1992), pp. 978985.

5) de Matteis, G.: Longitudinal Dynamics of a Towed Sailplane, J. Guid. Control Dynam., 16 (1993), pp. 822-829.

6) Etkin, B.: Stability of a Towed Body, J. Aircraft, 35 (1998), pp. 197-205.

7) 柚原直弘, 佐藤親俊, 高橋哲昭: 飛行機によって曳航される Glider の飛行性について，第 11 回飛行機シンポジウム講演集，1973， pp. $125-128$.

8) 柚原直弘, 佐藤親俊 : 曳航体の動安定解析について, 第 23 回飛 行機シンポジウム講演集, 1985, pp. 298-301.

9) Von Flotow, A. H. and Wereley, N. M.: Insight and Approximations in Dynamic Analysis of Spacecraft Tethers Mechanics and Control of Large Space Structures, Progress in Astronautics and Aeronautics, Junkins, J. L., ed., AIAA, Washington, DC, 1990, pp. 667-696.

10) Hoener, S. F.: Fluid Dynamic Drag Hoener, Midland Park, NJ, 1958.

11) Pestel, E. C. and Leckie, F. A.: Matrix Methods in ElastoMechanics, McGraw-Hill, New York, 1975.

12) 日本航空宇宙学会編 : 航空宇宙工学便覧, 丸善, 東京, 1974, pp. 254-256.

13) Etkin, B.: Dynamics of Atmospheric Flight, John Wiley \& Sons, New York, 1972. 